\title{
OPTIMIZING WORK ONLINE SERVICES BASED INAPORTNET TO INCREASE SERVICE ON SHIPPING ARRIVAL AT PT MASKAPAI PELAYARAN PULAU LAUT PANJANG BRANCH
}

\author{
Retno Indriyati ${ }^{1)}$, Baharudinsyah Dwiputra Novarizal ${ }^{2)}$ \\ 1) Program Studi Nautika Akademi Pelayaran Niaga Indonesia \\ e-mail : $\underline{\text { retno@akpelni.ac.id }}$ \\ 2) Taruna Program Studi Ketatalaksanaan Pelayaran Niaga Indonesia \\ Akademi Pelayaran Niaga Indonesia
}

\begin{abstract}
This writing aims to find out about Standard Operating Procedure and Service Level Agreement Inaportnet system, from before the ship arrived until the management of ship permit out. In carrying out the ship agency's duties which include ship clearance activities with Inaportnet, it is necessary to have knowledge of Inaportnet application form.

Data collection methods used in the writing of Scientific Writing is a method of observation or observation, interview or interview method, literature study method and documentation method.

The results of the writing show that online services based on Inaportnet can facilitate the tasks of the users of sea transport services in serving the arrival of ships in the Port of Bandar Lampung. However, there are still obstacles in the application of Inaportnet system such as low quality of service, network interruption on server, lack of utilization of science and technology and complicated application usage procedure.

The result of this writing can be concluded that Inaportnet-based online service is a single electronic information service system based on internet to integrate port system of information which nature standard serve ship and goods from all related institution or stakeholder at port.
\end{abstract}

Keywords: Clearance in / out, agency, agent, Inaportnet and documents 


\section{A. Latar Belakang}

Indonesia adalah negara yang dikenal sebagai negara maritim yang sebagian besar luas wilayahnya merupakan perairan dan terdiri atas pulau - pulau. Di atas teritorial daratan dan perairan tersebut membentang pula udara yang semuanya itu merupakan wilayah Indonesia. Keadaan wilayah Negara Indonesia yang sangat luas membutuhkan banyak transportasi guna mempermuadah distribusi baik makanan ataupun barang melalui daratan, perairan, maupun udara yang mampu menjangkau seluruh wilayah Negara Indonesia bahkan ke mancanegara.

Mengingat keadaan geografis Indonesia sebagai Negara kepulauan terbesar di dunia dan dua pertiga wilayahnya merupakan perairan, Indonesia membutuhkan transportasi laut untuk mendukung distribusi barang secara efektif. Sumberdaya laut dari sudut ekonomi mempunyai keunggulan komparatif, sedangkan posisinya dapat menjadi keunggulan kompetitif. Oleh sebab itu, sarana transportasi laut sangat penting untuk menghubungkan pulaupulau yang tersebar diseluruh Indonesia. Salah satu sarana transportasi laut adalah kapal laut. Kapal adalah kendaraan pengangkut penumpang atau barang di laut, sungai dan lain sebagainya.

Sebagai salah satu komponen utama dalam sistem transportasi laut, diperlukan adanya peran penting dari pelabuhan.
Pelabuhan merupakan sebuah fasilitas di ujung samudera, sungai, atau danau sarana bongkar muat kapal baik barang maupun penumpang. Indonesia memiliki banyak pelabuhan besar yang terbentang dari Sabang sampai Merauke. Salah satu pelabuhan besar tersebut adalah Pelabuhan Panjang yang terletak di Bandar Lampung. Pelabuhan Panjang merupakan salah satu pintu gerbang keluar masuknya barang dari dan keluar Pulau Sumatra. Karena letaknya yang strategis, secara tidak langsung turut mempengaruhi tingkat aktifitas di pelabuhan. Kapal-kapal yang melakukan aktifitas di Pelabuhan Panjang Bandar Lampung mengalami pertumbuhan pada tiap tahunnya sehingga diperlukan suatu sistem terintegrasi yang mampu menangani pelayanan kapal secara cepat dan efisien mengingat banyaknya instansi yang terkait dalam proses ini. Kementrian Perhubungan memberi respon dengan menyiapkan suatu wadah (portal) yang diitegrasikan dengan seluruh pola kegiatan baik pelayanan dan perizinan dari intansi terkait yang melaksanakan kegiatan di pelabuhan yang dinamakan Inaportnet. Sejak mulai diimplementasikan, sistem Inaportnet masih terbilang rumit. Permasalahan itu lebih ditekankan karena adanya masa transisi antara system lama yang manual dengan system baru yang sudah otomatisasi atau menggunakan teknologi. Disamping itu penerapan sistem Inaportnet yang melibatkan 
banyak intansi terkait, sangat membutuhkan dukungan dan partisipasi aktif dari seluruh pengguna jasa yang memiliki hubungan serta kepentingan terhadap layanan Inaportnet, terutama dengan karakteristik sistem Inaportnet yang merupakan proses integrasi dan kolaborasi sistem dari semua intansi. Dengan semakin berkembangnya suatu pelayanan, maka akan beradampak pada pelayanan ekspor impor yang semakin baik, oleh karena itu Kementrian Perhubungan harus meningkatkan pelayanan, dan kualitas sumber daya manusia yang ada di setiap Instansinya.

PT. Maskapai Pelayaran Pulau laut Cabang Panjang yang bergerak di bidang keagenan kapal sudah menerapkan sistem Inaportnet sejak 16 September 2017. Tetapi dalam prakteknya masih ditemukan beberapa masalah dalam penerapan sistem Inaportnet tersebut, antara lain rumitnya Standar Operating Procedure dan Service Level Agreement di sistem Inaportnet serta kurang pahamnya agen pelayaran terhadap bentuk aplikasi Inaportnet pada pelayanan kapal.

\section{B. Pengertian Inaportnet, Fungsi Inaportnet, Keagenan dan Perusahaan Pelayaran, Pelabuhan}

\section{Inaportnet}

$\begin{array}{lr}\text { Menurut } & \text { Kementrian } \\ \text { Perhubungan } & \text { Republik } \\ \text { Indonesia Direktorat Jendral } \\ \text { Perhubungan } & \text { Laut } \\ \text { mengatakan, } & \text { Inaportnet } \\ \text { didefinisikan sebagai sistem }\end{array}$

informasi layanan tunggal secara elektronik berbasis internet untuk mengintegrasikan sistem informasi kepelabuhanan yang berstandar melayani kapal dan barang dari seluruh Instansi terkait atau pemangku kepentingan di pelabuhan (termasuk sistem layanan Badan Usaha Pelabuhan / BUP ).

Dari pengertian diatas dapat disimpulkan bahwa Inaportnet adalah suatu sistem dimana tersedianya suatu wadah (portal) untuk dioperasikan dan diintegrasikannya untuk seluruh pola kegiatan baik pelayanan dan perizinan (Clearance) dari intansi terkait yang melaksanakan kegiatan di pelabuhan, sehingga akan mampu meningkatkan kinerja penanganan atas kegiatan perdagangan dan lalu lintas barang, terutama mendorong percepatan proses Port Clearance. Inaportnet mengintegrasikan layanan kebutuhan administrasi perkapalan di seluruh instansi terkait di pelabuhan. Inaportnet memungkinkan pengurusan administrasi secara online terintegrasi untuk surat izin kelaikan berlayar, surat izin kesehatan kapal, surat bebas karantina, ijin masuk dan keluar bagi crew kapal, serta berbagai hal lain yang diperlukan sebuah kapal saat tiba sandar atau berlayar. 
Penerapan layanan online berbasis Inaportnet dititik beratkan pada pelayanan Port Clearance yang memakan waktu cukup lama di Pelabuhan Indonesia terutama untuk kapal-kapal asing yang melakukan kegiatan bongkar dan muat di Pelabuhan Panjang Bandar Lampung. Hal demikian terjadi karena masih adanya keterbatasan kemampuan dalam pelayanan kapal dan barang baik yang bersifat teknis atau administratif. Dengan adanya layanan online berbasis Inaportnet yang melibatkan banyak entitas mulai dari instansi pemerintah sampai pihak swasta sehingga pihak-pihak yang berkaitan dengan proses Port Clearance tidak perlu membawa hardcopy (paperless) dalam pelaksanaan Port Clearance untuk kapal-kapal yang ingin sandar di Pelabuhan Panjang Bandar Lampung.

$\begin{array}{lr}\text { Pengguna } & \text { Inaportnet } \\ \text { mencakup } & \text { Instansi } \\ \text { pemerintah yang terdiri dari } \\ \text { Pelabuhan } & \text { Indonesia } \\ \text { (Pelindo) } & \text { dan } \\ \text { Kesyahbandaran } & \text { dan } \\ \text { Otoritas Pelabuhan } & \text { (KSOP) } \\ \text { serta pihak r rwasta } \\ \text { Perusahaan } & \text { Pelayaran } \\ \text { (agen), Perusahaan Bongkar } \\ \text { Muat (PBM) dan Ekspedisi } \\ \text { Muatan Kapal r Laut } \\ \text { (EMKL) dalam } & \text { bentuk } \\ \text { portal yang mampu diakses } \\ \text { pengguna jasa angkutan laut } \\ \text { tanpa harus datang ke }\end{array}$

instansi terkait (paperless) kecuali permasalahan diluar sistem. Karakteristik Inaportnet yaitu:

a. Berbasis web: Selalu dapat diakses dimana saja dan kapan saja

b. Mudah digunakan bagi para pengguna jasa angkutan laut

c. Aman : Pertukaran data dan informasi terjamin kerahasiaannya

d. Cerdas : Sistem dapat menyesuaikan dengan kondisi pengguna.

e. Netral: Tidak memihak, sistem hanya memberikan akses sesuai dengan tingkat kepentingan pengguna.

Sedangkan untuk mempermudah pelayanan terhadap pelaku industri logistik di Indonesia, maka layanan online berbasis Inaportnet harus memberikan beberapa fungsi - fungsi yang terdiri sebagai berikut :

a. Single submission yaitu mempermudah proses

b. Layanan online yang berfungsi menghemat waktu dan biaya bagi pengguna jasa transportasi

c. Mempercepat proses layanan secara keseluruhan bagi pengguna jasa angkutan laut

d. Meminimalisir kesalahan memasukan data dan dokumen untuk pelayanan kapal 
e. Mempermudah

monitoring penggunaan layanan Inaportnet

f. Meningkatkan daya saing pengguna jasa angkutan laut.

\section{Keagenan}

Keagenan menurut R.P. Suyono (2007:223), Keagenan adalah hubungan berkekuatan secara hukum yang terjadi bilamana dua pihak bersepakat membuat perjajian, dimana salah satu pihak yang dinamakan agen (agent) setuju untuk mewakili pihak lainnya yang dinamakan pemilik (principal) dengan syarat bahwa pemilik tetap mempunyai hak untuk mengawasi agennya mengenai kewenangan yang dipercayakan kepadanya. Apabila suatu kapal berlabuh di suatu pelabuhan maka kapal tersebut membutuhkan pelayanan dan memiliki berbagai keperluan yang harus dipenuhi. Untuk melayani berbagai keperluan tersebut, perusahaan pelayaran akan menunjuk sebuah agen kapal. Sedangkan untuk meningkatkan pelayanan terhadap General Agent maka agen harus menjalankan fungsi - fungsinya antara lain

\footnotetext{
a. Menyusun program operasional keagenan berdasarkan kebijakan perusahaan, baik terhadap pelayanan liner service maupun tramper.
}

b. Mengusahakan kegiatan keagenan sedemikian rupa sehingga dapat memberikan stimulan terhadap kegiatan kegiatan pokok perusahaan.

c. Mengawasi pelaksanaan penanganan/pelayanan keagenan, baik yang bersifat kegiatan fisik maupun kegiatan jadwal datang dan keberangkatan kapal.

d. Memanajemen kegiatan keagenan, baik yang berkaitan dengan kegiatan fisik operasional maupun yang menyangkut keuangan.

e. Memberikan data dan evaluasi terhadap perkembangan kegiatan keagenan sebagai masukan dalam menentukan kebijakan sebagaimana mestinya.

\section{Perusahaan Pelayaran}

Menurut Peraturan Menteri Perhubungan Nomor 93 Tahun 2013 pasal 1 ayat 6 , perusahaan pelayaran adalah perusahaan angkutan laut berbadan hukum indonesia, yang dalam melakukan kegiatan usahanya dengan menggunakan kapal layar, baik itu kapal layar motor tradisional atau kapal layar berukuran tertentu.

Maka dari pengertian tersebut dapat disimpulkan bahwa perusahaan pelayaran merupakan usaha industri jasa transportasi laut yang memberikan manfaat sangat besar bagi perpindahan suatu barang melalui perairan, baik 
secara 'place utility' maupun 'time utility'. Berdasarkan kegiatannya pelayaran terbagi atas pelayaran niaga dan pelayaran non-niaga. Adapun berdasarkan trayek yang dilayari terbagi atas kegiatan pelayaran nasional dan kegiatan pelayaran internasional.

\section{Pelabuhan}

Pelabuhan menurut Peraturan Pemerintah No.69 Tahun 2001 pasal 1 ayat 1, tentang Kepelabuhanan, pelabuhan merupakan suatu wilayah yang terdiri atas daratan, perairan dengan batas tertentu sebagai tempat untuk melakukan kegiatan pemerintah dan kegiatan ekonomi yang digunakan sebagai tempat untuk bersandar kapal, berlabuhnya kapal, naik atau turunnya penumpang dan bongkar muat barang yang dilengkapi dengan fasilitasfasilitas keselamatan pelayaran dan kegiatan penunjang serta sebagai tempat perpindahan intra dan antar moda.

Sedangkan menurut Undang-Undang No. 17 Tahun 2008 mengenai Pelayaran, pelabuhan adalah tempat yang terdiri atas daratan dan atau perairan dengan batas-batas tertentu sebagai tempat berkegiatan pemerintah dan perusahaan. Secara fisik, pelabuhan dipergunakan sebagai tempat kapal berlabuh, naik turun penumpang dan atau bongkar muat barang.

\section{Pembahasan}

1. Analisis Efektifitas Waktu Pelayanan Kapal Masuk via Inaportnet

Berdasarkan Standar

Operating Procedure dan Service Level Agreement pada pelayanan kapal masuk via layanan online berbasis Inaportnet, dapat di analisa beberapa hal yang merupakan keunggulan layanan online Inaportnet dibandingan dengan sistem perizinan secara manual antara lain:

a. Total waktu yang dibutuhkan untuk penerbitan dokumen perijinan layanan kapal masuk (Clearance In) via layanan online berbasis Inaportnet dengan seluruh instansi terkait di Pelabuhan adalah 7 jam 30 menit.

b. Sebelum kapal tiba dan berlabuh seluruh perizinan Clearance In kapal telah diterbitkan oleh masing-masing intansi terkait di Pelabuhan.

c. Tidak terjadi waktu tunggu pelayanan pemanduan.

d. Kegiatan bongkar dan muat dapat dijalankan lebih awal dan tepat waktu serta waktu kapal di Pelabuhan dapat lebih singkat.

e. Tersedia waktu 4 jam 30 menit bagi agen pelayaran untuk melakukan perubahan atau pembatalan terhadap rencana 
pelayanan yang telah ditetapkan.

\section{Analisis Efektifitas Waktu Pelayanan Kapal Pindah via Inaportnet}

Berdasarkan

Standar

Operating Procedure dan

Service Level Agreement pada pelayanan kapal pindah via layanan online berbasis Inaportnet, dapat dianalisa beberapa hal yang merupakan keunggulan portal Inaportnet dibandingkan dengan sistem manual antara lain:

a. Total waktu penyelesaian dokumen perijinan dan persiapan fasilitas oleh agen pelayaran untuk kapal pindah via Inaportnet adalah 2 jam 30 menit.

b. Permintaan perijinan dan pelayanan fasilitas yang diajukan oleh agen pelayaran yaitu 4 jam sebelum kapal bergerak dari tempat tambat, dengan demikian terdapat sisa waktu 1 jam 30 menit bagi agen pelayaran untuk melakukan persiapan kapal pindah.

3. Analisis Efektifitas Waktu Pelayanan Kapal Keluar via Inaportnet

Berdasarkan Standar Operating Procedure dan Service Level Agreement pada pelayanan kapal keluar via layanan online berbasis Ianportnet, dapat dianalisa beberapa hal yang merupakan keunggulan portal Inaportnet dibandingkan dengan sistem Clearance manual antara lain:

a. Total waktu penyelesaian dokumen perijinan adalah 5 jam.

b. Terdapat sisa waktu 1 jam bagi agen pelayaran untuk melakukan persiapan keberangkatan kapal.

4. Kendala yang Sering Terjadi dalam Sistem Inaportnet

Dalam layanan online berbasis Inaportnet ini masih terdapat beberapa kendala dalam Standar Operating Procedure dan Service Level Agreement serta bentuk aplikasi Inaportnet yang dikerjakan oleh agen pelayaran sehingga menghambat kerja bagi para pengguna jasa angkutan laut, masalah-masalah yang sering terjadi antara lain:

a. Kualitas Layanan Rendah Masih rendahnya kualitas layanan dapat mempengaruhi

Operasional Prosedur sistem Inaportnet. Pelayanan publik yang baik merupakan fasilitas utama yang harusnya disediakan oleh Ditjen Hubla kepada pengguna jasa Inaportnet. Kenyataannya dalam sistem Inaportnet terkadang masih ditemukan pelayanan yang tidak sesuai dengan keinginan para pengguna jasa. Dalam kasus tersebut 


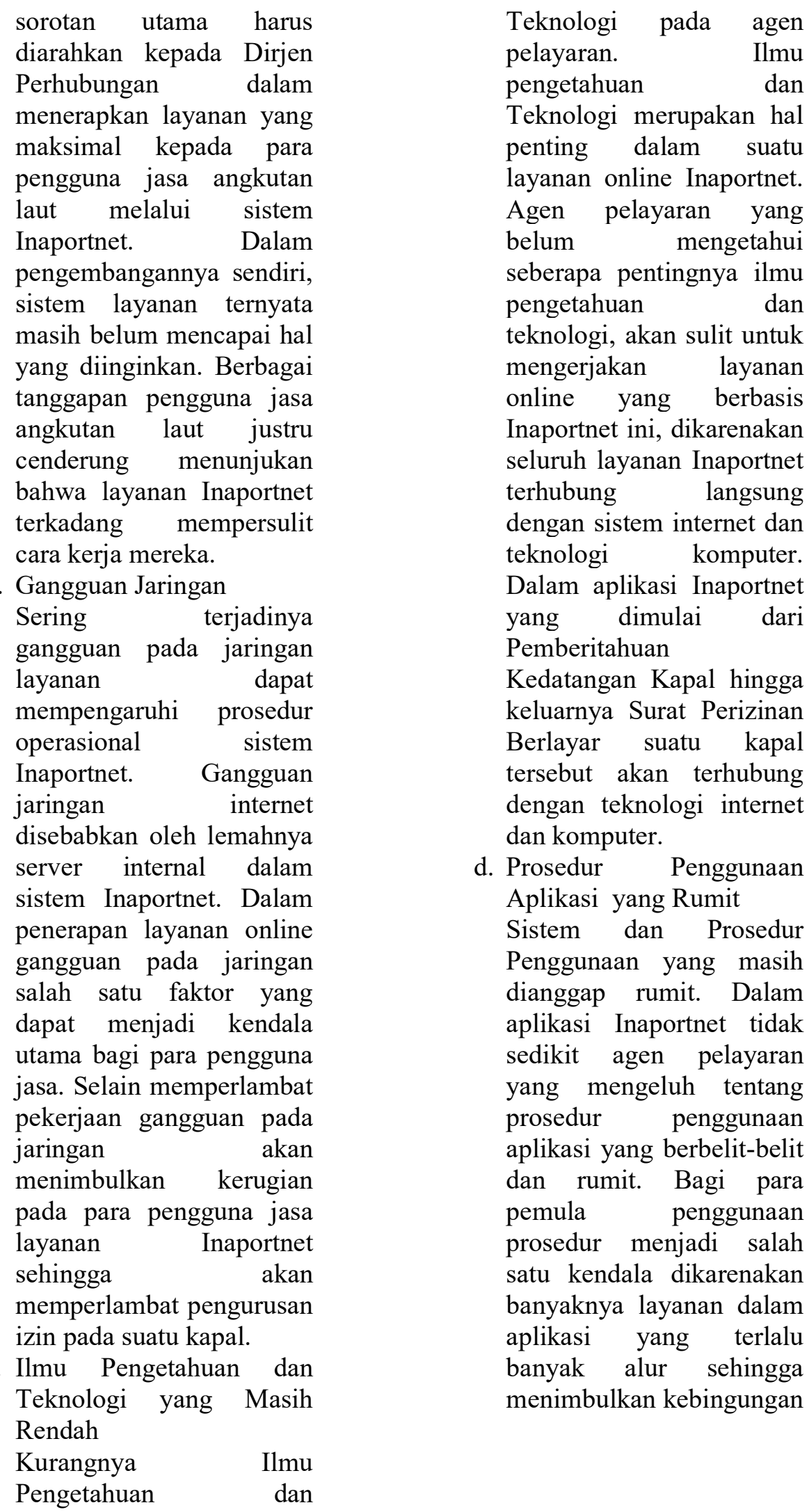


D. Kesimpulan

1. Dalam rangka menjadikan Indonesia sebagai Tol laut, pemerintah melalui Departemen Perhubungan telah melakukan optimalisasi kerja layanan online berbasis Inaportnet di Pelabuhan Panjang Bandar Lampung diantaranya dengan penerapan Standar Operating Procedure dan Service Level Agreement. SOP dan SLA sendiri disusun untuk memudahkan, merapikan dan menertibkan layanan Inaportnet sehingga menghasilkan pelayanan yang maksimal terhadap pengguna jasa angkutan laut.

2. Meningkatkan kualitas jaringan internet karena bentuk aplikasi layanan online berbasis Inaportnet yang meliputi penunjukan, PKK serta pengajuan warta kedatangan via Inaportnet, persiapan dokumen untuk dimasukan dalam warta kedatangan, pegajuan permohonan olah gerak via Inaportnet, persiapan clearance out, pengajuan warta keberangkatan via Inaportnet, penerbitan Surat Izin Berlayar, dan kapal berangkat adalah satu kesatuan, dan apa bila ada salah satu proses yang terlewati maka agen pelayaran tidak bisa melakukan kegiatan keagenan kapal via layanan online berbasis Inaportnet.

3. Meningkatkan Pengetahuan dan Teknologi sebagai salah satu upaya Optimalisasi kerja perusahaan. Pada dasarnya kinerja yang baik yaitu mengikuti tata cara atau prosedur sesuai standar yang telah ditetapkan. Maka dari itu pihak atasan perusahaan terkait mesti turun kelapangan agar bisa mengawasi langsung bagaimana kinerja karyawan dalam menangani layanan Inaportnet yang baik dan maksimal sehingga dapat meningkatkan kualitas layanan kepada konsumen.

4. Sosialisasi yang selama ini dilakukan diharapkan terus berlanjut mengingat banyaknya karyawan yang masih kesulitan dalam penggunaan sistem Inaportnet walaupun sudah diberikan buku petunjuk manualnya. 


\section{DAFTAR PUSTAKA}

Kementrian Perhubungan Republik Indonesia Direktoral Jendral Perhubungan Laut. Power Point diakses pada tanggal 12 Mei 2018

Peraturan Pemerintah No.69 Tahun 2001 pasal 1 ayat 1

Sasono, Herman Budi. 2012. Manajemen Pelabuhan \& Realisasi ekspor Import. Yogyakarta: CV. Andi Offset.
Suyono, R.P. 2007. SHIPPING: Pengangkutan Intermodal Ekspor Impor Melalui Laut.Jakarta Pusat: Lembaga Manajemen PPM dan Anggota Ikapi.

Wahyono. 2009. Indonesia negara Maritim. Jakarta: Penerbit Teraju.

Waseso, Hendri Purbo. Muhtar Sofwan Hidayat. 2016. Mengaplikasikan Kurikulum Berbasis KKNI. Wonosobo: Mangku Bumi. 